KONSTRUKTIVISME, Vol. 8, No. 1, Januari 2016

p-ISSN: 1979-9438, e-ISSN: 2445-2355

FKIP Universitas Islam Balitar, Blitar

Web: konstruktivisme.unisbablitar.ejournal.web.id

\title{
ANALISIS KESULITAN MAHASISWA DALAM \\ PERKULIAHAN DAN PRAKTIKUM KIMIA DASAR \\ DI JURUSAN PENDIDIKAN BIOLOGI FKIP UNISBA
}

\author{
Dian Puspita Anggraini \\ Jurusan Pendidikan Biologi, Universitas Islam Balitar \\ Jl. Majapahit No. 2-4 Blitar \\ Email: dpuspita4@gmail.com
}

\begin{abstract}
The objective of this study is to see reasons of learning obstacles on learning process and practicum of basic chemistry course in relation with practicum and mastery of the theory. The study used descriptive design and collected data using test and questionnaire. The study assigned 40 students of biology Class at UNISBA. The study revealed that problems on learning basic chemistry is the mastery of teaching materials. Percentage of the problems is contributed in trems of: (1) practicum process $53.29 \%$, (2) teaching process $66.26 \%$, and (3) practicum implementation $66.26 \%$. On social factor, statistically contributes problems up to $66.15 \%$.
\end{abstract}

Keywords: basic chemistry, practicum, learning problems.

\begin{abstract}
Abstrak
Penelitian ini bertujuan untuk mengetahui penyebab kesulitan belajar pada proses pembelajaran dan pelaksanaan praktikum kimia dasar serta korelasi antara pelaksanaan praktikum dan teori matakuliah kimia dasar. Penelitian menggunakan rancangan deskriptif dan menggunakan tes dan angket untuk menjaring data. Subjek penelitian ialah mahasiswa Program Studi Pendidikan Biologi di UNISBA sebanyak 40 orang. Hasil penelitian menunjukkan hambatan yang menyebabkan kesulitan belajar kimia dasar mahasiswa jurusan pendidikan biologi adalah penguasaan materi. Persentase kesulitan diperoleh dari (1) proses pelaksanaan praktikum 53,29\%, (2) proses pembelajaran 8,69\%, dan (3) pelaksanaan praktikum sebesar $66,26 \%$. Pada faktor lingkungan masyarakat, secara statistik memiliki pengaruh cukup besar yaitu $66,15 \%$.
\end{abstract}

Kata-kunci: kesulitan belajar, kimia dasar

Kemajuan IImu Pengetahuan dan Teknologi (IPTEK) menjadi salah satu faktor ukuran berkembangnya suatu daerah lebih-lebih suatu bangsa atau negara. Perkembangan IPTEK bertumpu pada pengembangan 
Anggraini, P. Dian. 2016. Analisis Kesulitan Mahasiswa dalam Perkuliahan 63 dan Praktikum Kimia Dasar di Jurusan Pendidikan Biologi FKIP UNISBA.

Konstruktivisme, 8(1): 61-71.

potensi potensi sumber daya alam dan sumber daya manusia. Oleh sebab itu dalam dinamika pembangunan nasional senantiasa diperlukan upaya peningkatan sumber daya manusia. Titik berat peningkatan sumber daya manusia berada pada lingkungan pendidikan. Indikatornya berkaitan dengan upaya peningkatan kualitas hasil belajar siswa di sekolah atau mahasiswa di perguruan Tinggi. Kesulitan belajar menjadi suatu kendala yang mengemuka yang dialami siswa di Sekolah atau mahasiswa di Perguruan Tinggi. Sehingga kesulitan belajar menjadi salah satu akar permasalahan dalam perkembangan IPTEK.

Kesulitan belajar merupakan suatu kondisi yang dialami siswa atau mahasiswa yang ditandai dengan adanya hambatan-hambatan tertentu yang menyebabkan tidak tercapainya tujuan belajar. Terdapat berbagai faktor yang mempengaruhi ketidak tercapaian tujuan belajar yang terukur pada keberhasilan pembelajaran yaitu: kapasitas mahasiswa, kualitas guru/dosen, kualitas lingkungan pembelajaran, dan kualitas proses pembelajaran. Dari keempat faktor tersebut, dua yang paling dominan mempengaruhi keberhasilan pembelajaran yaitu; kapasitas mahasiswa, kualitas guru dan kualitas proses pembelajaran (Darminto, 2006).

Ilmu kimia sebagai salah satu cabang dari ilmu pengetahuan alam merupakan ilmu yang mempelajari tentang sifat materi, struktur materi, perubahan materi serta energi yang menyertai reaksi kimia. Mata pelajaran kimia merupakan salah satu mata pelajaran di sekolah yang sekarang ini baru mulai diajarkan pada tingkat Sekolah Menengah Atas (SMA) dan lebih lanjut dipelajari lebih mendalam di perguruan tinggi. Ilmu Kimia termasuk salah satu ilmu kunci dari IImu IPA sebagai dasar IPTEK.

Di Program Studi Pendidikan Biologi Fakultas KIP UNISBA, pelajaran kimia di berikan pada semester awal dengan matakuliah Kimia Dasar. Mata kuliah ini bermuatan 3 satuan kredit semester (SKS) yang terintegrasi dengan praktikum. Untuk perkuliahan bernilai 2 SKS dan untuk praktikum bernilai 1 SKS. Pada praktikum Kimia Dasar mahasiswa diharapkan dapat dibekali penguasaan psikomotorik yang didukung dengan afektif dan kognitif. Pelaksanaan praktikum dievaluasi mengikuti tatacara tertentu mulai dari responsi (evaluasi pemahaman mahasiswa terhadap apa yang akan dilakukan dilaboratorium baik itu berupa teori maupun prosedur kerja praktikum), evaluasi aktivitas (keaktifan), laporan dan ujian akhir matakuliah.

Matakuliah Kimia Dasar yang diajarkan di Jurusan Pendidikan Biologi FKIP UNISBA memuat materi yang disusun berdasarkan kompetensi dasar yang diharapkan tercipta pada mahasiswa. Materi tersebut yaitu; terdiri dari stokiometri, energkinetika kimia, kimia larutan, kinetika kimia, eletrokimia, radiokimia dan biokimia (karbohidrat dan protein). Semua materi -materi tersebut telah dipelajari di SMA, dengan demikian mata kuliah Kimia Dasar bukan hal yang baru bagi mahasiswa, sehingga dalam pelajaran akan lebih mudah. Selain itu, mata kuliah Kimia Dasar diharapkan mahasiswa baru sudah memiliki bekal kemampuan dasar untuk mengikuti perkuliahan kimia dasar. Kemampuan dasar yang diharapkan dimiliki oleh mahasiswa pada semester satu tentunya dapat menjadi modal yang digunakan untuk mempermudah pencapaian tujuan pembelajaran yang tertuan pada 
prestasi belajar. Berdasarkan fakta dilapangan, ditemukan bahwa antar kenyataan dan harapan masih terpaut sangat jauh. Masih banyak mahasiswa baru yang mengambil matakuliah ini masih memperoleh nilai dibawah standar dan banyak yang mengalami kesulitan belajar.

Kesulitan belajar ini tergambar pada sebaran nilai kelulusan mahasiswa untuk mata kuliah Kimia Dasar pada semester ganjil tahun akademik 2014/2015 dengan jumlah mahasiswa sebanyak 119 orang adalah 18 orang memperoleh nilai $A, 27$ orang memperoleh nilai $B, 50$ memperoleh nilai C, 13 memperoleh nilai $D$ dan sisanya 11 orang memperoleh nilai E (Administrasi Jurusan Biologi FKIP UNISBA 2014). Dengan demikian, $42 \%$ mahasiswa memperoleh nilai kelulusan minim, dan terdapat sekitar 21\% yang tidak lulus. Bahkan dari 119 yang memprogramkan mata kuliah Kimia Dasar tahun akademik 2014/2015 tersebut sekitar $31,01 \%$ adalah mahasiswa yang mengulang berstatus mengulang. Hal ini memberikan bukti bahwa masih banyak mahasiswa mengalami kesulitan dalam perkuliahan dan praktikum Kimia Dasar sehingga hasil belajar yang diinginkan tidak tercapai sebagaimana mestinya.

Salah satu penyebab awal kesulitan belajar siswa adalah anggapan siswa yang tidak pernah hilang bahwa kimia merupakan salah satu mata pelajaran yang sulit dipahami. Pemahaman yang melekat pada siswa ini mempengaruhi minat belajar siswa yang menurun sehingga pada akhirnya berdampak pada rendahnya hasil belajar. Selain daripada itu, hal yang juga dapat menjadi ukuran untuk mengetahui penyebab kesulitan belajar siswa adalah hambatan-hambatan yang dialami mahasiswa dalam proses pembelajaran. Hambatan yang dimaksud yaitu; pada kompetensi pendukung dalam penguasaan konsep, pada proses pembelajaran, dan pada faktor lingkungan mahasiswa. Kesulitan belajar pada penelitian diungkap pada faktor hambatan yang menjadi penyebab kesulitan belajar mahasiswa pada matakuliah kimia dasar di Jurusan Pendidikan Biologi FKIP UNISBA, hambatan yang menyebabkan adanya kesulitan belajar pada mahasiswa pada praktikum serta korelasi antara pelaksanaan praktikum dan teori matakuliah kimia dasar.

\section{METODE \\ Jenis penelitian}

Penelitian ini merupakan penelitian dekskriptif analisis yang dilaksanakan selama satu semester. Metode penelitian yang digunakan berbeda sesuai untuk masing-masing cakupan penelitian yang dilakukan secara bersama disesuaikan dengan tahapan dan tujuan penelitian. Secara keseluruhan penelitian ini merupakan gabungan hasi-hasil penelitian dari empat penelitian; studi kesulitan pada konten matakuliah kimia dasar, studi keterkaitan praktikum dan teori matakuliah kimia dasar, studi kesulitan belajar di sekolah, dan studi kesulitan dari hambatan eksternal mahasiswa.

\section{Subjek Penelitian}

Subjek dalam penelitian ini terbagi berdasarkan arah penelitian. 
Anggraini, P. Dian. 2016. Analisis Kesulitan Mahasiswa dalam Perkuliahan 65 dan Praktikum Kimia Dasar di Jurusan Pendidikan Biologi FKIP UNISBA.

Konstruktivisme, 8(1): 61-71.

untuk kesulitan belajar yang diukur dari penguasaaan materi dan hambatan dalam praktikum serta korelasi praktikum dengan teori yakni mahasiswa jurusan pendidikan biologi angkatan 2014 FKIP Universitas Islam Balitar Blitar tahun akademik 2014/2015. Untuk kesulitan belajar siswa adalah siswa tempat mahasiswa penelitian.

\section{Teknik Pengumpulan Data}

Secara umum data yang penelitian yang dikumpulkan yaitu;

a. untuk data hambatan kesulitan yang berhubungan dengan kemampuan dasar matematika dengan indikator; (penguasaan materi matematika yang menunjang dan membantu pemahaman materi seperti perkalian, pembagian dan operasi perkalian bilangan berpangkat) dan kesulitan yang berhubungan dengan pengetahuan dasar kimia, pemahaman penerapan konsep kimia dilakukan melalui instrumen test yang dibuat sedemikian rupa untuk mengukur kesulitan tersebut dan suda divalidasi oleh validator.

b. untuk data hambatan pada proses pembelajaran, pelaksanaan praktikum, dan korelasi pelaksanaan praktikum kimia dasar diperoleh melalui angket penelitian yang dikembangkan dan divalidasi.

\section{Teknik Analisis Data}

Analisis data yang digunakan dalam penelitian ini adalah;

a. untuk data hambatan kesulitan yang berhubungan dengan kemampuan dasar matematika (mengenai penguasaan materi matematika yang menunjang dan membantu pemahaman materi seperti perkalian, pembagian dan operasi perkalian bilangan berpangkat) dan kesulitan yang berhubungan dengan pengetahuan dasar kimia, pemahaman penerapan konsep kimia dan data hambatan pada proses pembelajaran, pelaksnaan praktikum, dan korelasi pelaksanaan praktikum kimia dasar diperoleh melalui angket dianalisis dengan persentase berdasarkan indikator kesulitan yang dibuat. Nilai selanjutnya dikategorikan seperti pada Tabel 1.

b. untuk hambatan eksternal digunakan model analisis faktor untuk mengungkap faktor-faktor eksternal yang mempengaruhi kesulitan dalam perkuliahan dan praktikum kimia dasar di jurusan pendidikan biologi FKIP Universitas Islam Balitar Blitar, dengan persamaan:

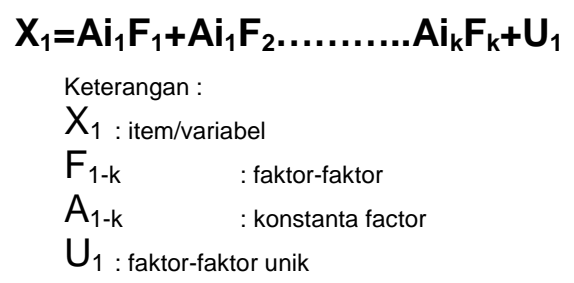

Syarat correlation matrix tiap item $>0$ koefisien community $>50 \%$ dan koefisien Keiser-Mayer-Olkin (KMO) 0,50-1,0. 
Tabel 1. Kategori Tingkat Kesulitan Berdasarkan Persentase

\begin{tabular}{|ccl|}
\hline No & $\begin{array}{c}\text { Skor } \\
\text { Kesulitan }\end{array}$ & \multicolumn{1}{c|}{$\begin{array}{c}\text { Kategori } \\
\text { Kesulitan }\end{array}$} \\
\hline 1. & $0-20$ & Sangat Rendah \\
2. & $21-40$ & Rendah \\
3. & $41-60$ & Sedang \\
4. & $61-80$ & Tinggi \\
5. & $81-100$ & Sangat Tinggi \\
\hline
\end{tabular}

\section{HASIL}

\section{Deskripsi Kesulitan pada Penguasaan Materi}

Data kesulitan belajar mahasiswa diukur berdasarkan tingkat penguasaan materi yang ditentukan berdasarkan instrumen yang dikembangkan yang dibuat dalam bentuk deskriptif persentase.

Hasil analisis data penelitian diperoleh berupa gambaran mengenai tingkat kesulitan yang dialami oleh mahasiswa

Jurusan Pendidikan Biologi dalam matakuliah kimia dasar menyangkut kemampuan dasar matematika, kemampuan dasar kimia, kemampuan memahami konsep materi dan kemampuan menganalisis hubungan antarkonsep. Deskripsi kesulitan belajar mahasiswa dapat dilihat pada Tabel 2.

Tabel 2. Tingkat Persentase Kesulitan Mahasiswa Jurusan Kimia dalam Menguasai Materi Kimia Dasar

\begin{tabular}{|c|c|}
\hline Indikator & $\begin{array}{l}\text { Presentase } \\
\text { kesulitan }\end{array}$ \\
\hline $\begin{array}{l}\text { Kemampuan } \\
\text { matematika }\end{array}$ & $44,28 \%$ \\
\hline Kemapuan dasar kimia & $36,45 \%$ \\
\hline $\begin{array}{l}\text { Kemampuan memahami } \\
\text { konsep materi }\end{array}$ & $61,31 \%$ \\
\hline $\begin{array}{l}\text { Kemampuan } \\
\text { menganalisis hubungan } \\
\text { antarkonsep }\end{array}$ & $71,13 \%$ \\
\hline Rata-rata & $53,29 \%$ \\
\hline
\end{tabular}

Melihat rata-rata persentase hambatan pada penguasaan materi kuliah dengan empat kategori yang dianalisis $53,29 \%$, nilai tergolonga cukup tinggi. Sehingga dapat dikatakan bahwa pada kemampuan mahasiswa untuk menguasai materi kimia cukup mengalami kesulitan.

\section{Hambatan dalam Proses Pembelajaran dan Pelaksanaan praktikum}


Anggraini, P. Dian. 2016. Analisis Kesulitan Mahasiswa dalam Perkuliahan 67 dan Praktikum Kimia Dasar di Jurusan Pendidikan Biologi FKIP UNISBA.

Konstruktivisme, 8(1): 61-71.

Hambatan dalam proses pembelajaran menyangkut performa pengajar dengan indikator yang dimaksudkan, kehadiran memberi kuliah, kedisiplinan, adanya buku rujukan, metode mengajar yang diterapkan kesesuaian materi dengan alat evaluasi.

Sedangkan pada pelaksanaan praktikum menyangkut, sarana prasarana, kondisi alat dan zat, dan ketenagaan. Deskripsi berupa persentase hambatan yang dialami mahasiswa dalam proses perkuliahan kimia dasar dapat dilihat pada Tabel 3. Sedangkan Deskripsi berupa persentase hambatan yang dialami mahasiswa dalam pelaksanaan praktikum dapat dilihat pada Tabel 4.

Tabel 3. Tingkat Persentase Hambatan dalam Proses Pembelajaran

\begin{tabular}{|lc|}
\hline \multicolumn{1}{|c|}{ Indikator } & $\begin{array}{c}\text { Persentase } \\
\text { Hambatan }\end{array}$ \\
$\begin{array}{l}\text { Kehadiran } \\
\text { memberi kuliah }\end{array}$ & $5,34 \%$ \\
$\begin{array}{l}\text { Kedisiplinan } \\
\text { Ketersediaan buku } \\
\text { rujukan }\end{array}$ & $1,23 \%$ \\
$\begin{array}{l}\text { Metode mengajar } \\
\text { Kesesuaian materi } \\
\text { dengan alat } \\
\text { evaluasi } \\
\quad \text { Rata-rata }\end{array}$ & $20,13 \%$ \\
\hline
\end{tabular}

Melihat rata-rata persentase hambatan pada proses pembelajaran $8,69 \%$, nilai tergolonga rendah. Sehingga dapat dikatakan bahwa pada proses perkuliahan mahasiswa tidak terlalu mengalami hambatan.

Tabel 4. Tingkat Persentase Hambatan dalam Pelaksanaan Praktikum

\begin{tabular}{|ll|}
\hline Indikator & $\begin{array}{l}\text { Persentase } \\
\text { Hambatan }\end{array}$ \\
\hline $\begin{array}{l}\text { Sarana } \\
\text { Prasarana }\end{array}$ & $65,40 \% \%$ \\
$\begin{array}{l}\text { Kondisi alat dan } \\
\text { zat }\end{array}$ & $75,15 \%$ \\
$\begin{array}{l}\text { Ketenagaan } \\
\text { Rata-rata }\end{array}$ & $58,22 \%$ \\
\hline
\end{tabular}

Melihat rata-rata persentase hambatan pada pelaksanaan praktikum $66,26 \%$, nilai tergolonga cukup tinggi. Sehingga dapat dikatakan bahwa pada pelaksanaan praktikum mahasiswa cukup mengalami hambatan belajar.

\section{Hambatan Faktor Eksternal}

Dari data hasil angket diperoleh secara deskriptif tingkat persentase hambatan dari lingkungan kampus dan lingkungan masyarakat yaitu dari kedelapan faktor. Analisis dilakukan dengan menganalisis jawaban para 
responden terhadap angket yang telah diujicobakan. Setelah kriteria data yang diolah dalam analisis faktor memenuhi kriteria correlation matriks $>0,5$, Koefesien communality tiap item > 0,5\% dan koefesien Kaiser-MayerOlkim tiap item berada pada nilai antara $0,5-1$ sehingga dapat dilakukan analisis faktor

Dari hasil analisis faktor, secara statistik didapatkan bahwa secara kseseluruhan dari delapn faktor yang diselidiki memiliki pengaruh sebesar $66,15 \%$, sehingga sisanya $33,08 \%$ dapat dikatakan sebagai fakor lain yang merupakan faktor yang dianggap tidak berpengaruh dalam penelitian ini. Dari kedelapan faktor, faktor sarana dan prasarana belajar di rumah mempunyai pengaruh yang paling besar dengan koefisien varian $11,399 \%$.

\section{Hubungan Nilai Praktikum dan Nilai Teori Kimia Dasar mahasiswa}

Adapun deskripsi yang berkaitan dengan nilai praktikum dan nilai teori mata kuliah Kimia dasar untuk mahasiswa program studi pendidikan biologi angkatan 2014 dapat dilihat pada Tabel 5.

Tabel. 5. Deskriptif Nilai praktikum Tateori

\begin{tabular}{|c|c|c|c|c|}
\hline \multirow[b]{2}{*}{ Variabel } & \multicolumn{2}{|c|}{ Nilai kelas A } & \multicolumn{2}{|c|}{ Nilai kelas B } \\
\hline & $\begin{array}{l}\text { Nilai } \\
\text { Teori }\end{array}$ & $\begin{array}{l}\text { Nilai } \\
\text { Prak. }\end{array}$ & $\begin{array}{l}\text { Nilai } \\
\text { Teori }\end{array}$ & $\begin{array}{l}\text { Nilai } \\
\text { Prak }\end{array}$ \\
\hline $\begin{array}{l}\mathbf{N} \\
\text { Rata- } \\
\text { rata } \\
\text { Std. }\end{array}$ & $\begin{array}{l}39 \\
67,61 \\
5 \\
12,46\end{array}$ & $\begin{array}{l}39 \\
66,50 \\
5 \\
6,749\end{array}$ & $\begin{array}{l}38 \\
30,94 \\
7 \\
9,659\end{array}$ & $\begin{array}{l}38 \\
68,99 \\
0 \\
6,312\end{array}$ \\
\hline Deviasi & 6 & & & \\
\hline
\end{tabular}

Berdasarkan Tabel 5, pengujian linearitas regresi untuk kelas A nilai $F$ hitung yang didapatkan sebesar 0,687 lebih kecil daripada nilai $F$ tabel 4,11 , maka dapat disimpulkan regresinya linear. Sedangkan untuk kelas $B$, nilai $F$ hitung sebesar 0,223 . lebih kecil daripada nilai $F$ table $(4,12)$, maka dapat disimpulkan regresinya linear. Secara keseluruhan (kelas $A$, dan $B$ ) nilai dari t hitung 19,374 t tabel 1,648. Dengan demikian disimpulkan bahwa terdapat korelasi yang berarti antara nilai praktikum dengan nilai teori Kimia Dasar mahasiswa.

\section{BAHASAN}

Melihat rata-rata persentase hambatan pada penguasaan materi kuliah dengan empat kategori yang dianalisis 53,29\%, nilai tergolong cukup tinggi. Sehingga dapat dikatakan bahwa kemampuan mahasiswa untuk menguasai materi kimia cukup mengalami kesulitan. Rata-rata persentase hambatan pada proses pembelajaran $8,69 \%$, nilai tergolonga rendah. Sehingga dapat dikatakan bahwa pada proses perkuliahan mahasiswa tidak terlalu mengalami hambatan. Dan rata-rata persentase hambatan pada pelaksanaan praktikum $66,26 \%$, nilai tergolonga cukup tinggi. Sehingga dapat dikatakan bahwa pada pelaksanaan praktikum mahasiswa cukup mengalami hambatan mengalami hambatan belajar. Dari ketiga 
Anggraini, P. Dian. 2016. Analisis Kesulitan Mahasiswa dalam Perkuliahan

dan Praktikum Kimia Dasar di Jurusan Pendidikan Biologi FKIP UNISBA.

Konstruktivisme, 8(1): 61-71.

faktor yang dinilai sebagai hambatan penyebab kesulitan belajar mahasiswa, faktor hambatan pelaksanaan praktikum terbesar kemudian hambatan pada penguasaan materi baru hambatan pada proses pembelajaran. Untuk lebih jelasnya perbandingan ketiganya jika dipersentasekan secara keseluruhan dapat dilihat dari grafik berikut:

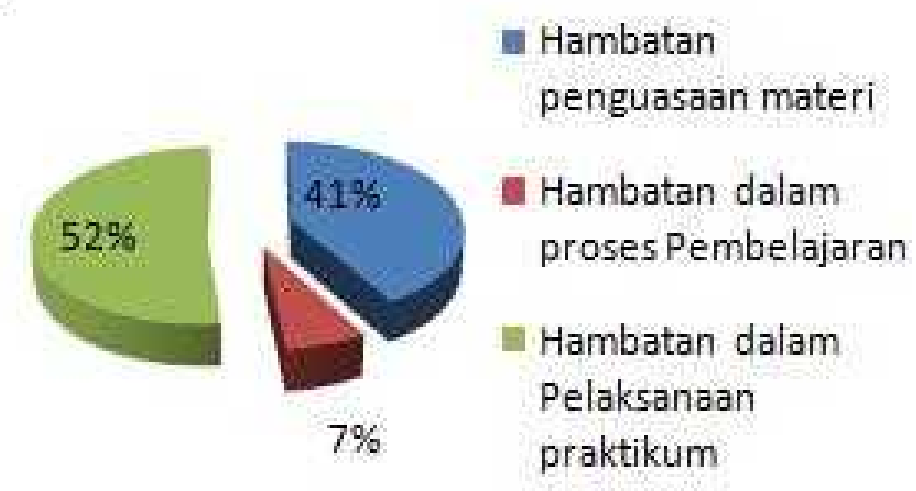

Gambar 1. Grafik Persentase (\%) Hambatan Mahasiswa pada Perkuliahan Kimia Dasar

Tiga faktor yang diteliti yang diduga sebagai hambatan dan penyebab terjadinya kesulitan belajar mahasiswa diatas memberikan gambaran bahwa faktor proses belajar mengajar dapat dikatakan tidak memberi kontribusi sebagai hambatan penyebab kesulitan belajara mahasiswa (Gambar 1). Tetapi pada bagian ini, indikator kesesuaian materi dengan alat evalusi dan metode mengajar tergolong cukup tinggi masing-masing $14,45 \%$ dan $20,13 \%$ dibandingkan dengan indikator yang lain. Sehingga pada indikator kesesuaian materi dan alat evaluasi mungkin dibutuhkan suatu standar (standar operasional prosedur (SOP) ) untuk penilaian begitu juga pada metode mengajar masih dibutuhkan peningkatan metode yang lebih baik dan lebih inovatif sehingga hambatan untuk proses pembelajaran tidak terlalu berarti sebagai penyebab kesulitan belajar kimia dasar mahasiswa di Jurusan Pendidikan Biologi FKIP UNISBA. Dua bagian yaitu; faktor penguasaan materi dan pelaksanaan praktikum dinilai mahasiswa cukup memberikan hambatan sebagai penyebab kesulitan belajar kimia dasar dengan rata-rata untuk keseluruhan indikator masing $53,29 \%$ dan $66,26 \%$.

Nilai ini lebih dari setengah yang bisa diartikan bahwa kesulitan belajar mahasiswa pada matakuliah kimia dasar berada pada faktor penyebab kesulitan penguasaaan materi dan pelaksanaan praktikum.

Hubungan antara nilai praktikum dan teori teori Kimia Dasar didapatkan bahwa ada sebagian mahasiswa yang memiliki nilai praktikum Kimia Dasar yang rendah namun memiliki nilai teori Kimia Dasar yang tinggi. Hal ini disebabkan karena mahasiswa tersebut mampu memahami dan siap dalam ujian mata kuliah Kimia Dasar secara teori, namun belum bisa mengintegrasikannya di dalam praktikum. Begitu pula sebaliknya, ada 
yang memiliki nilai praktikum yang tinggi namun memiliki nilai teori yang rendah. Hal ini disebabkan oleh karena mahasiswa tersebut mampu memahami dan melakukan praktikum dengan baik, melakukan kerja sama yang baik sesama praktikan dalam melakukan praktikum. Rendahnya nilai teori Kimia Dasar yang didapatkan disebabkan karena mahasiswa tersebut belum mampu mengintegrasikan apa yang didapatkan di praktikum dengan di perkuliahan. Selain itu, penilaian juga dilakukan dengan mempertimbangkan aspek afektif dari tiap mahasiswa.

Pelaksanaan praktikum Kimia Dasar didasarkan pada pembagian kelompok untuk tiap kelas dan praktikum yang dilakukan. Dalam sekali pertemuan, tiap kelompok melaksanakan praktikum yang berbeda-beda. Hal ini menyebabkan ada kelompok yang mendapatkan praktikum yang seharusnya belum didapatkan karena materi Kimia Dasar pada proses perkuliahan juga belum diterima. Pelaksanaan praktikum dengan proses perkuliahan Kimia Dasar idealnya berjalan secara bersama-sama.

Kekurangan alat dan bahan di Laboratorium merupakan hal yang paling berpengaruh terhadap jalannya praktikum. Pelaksanaan praktikum di laboratorium sangat tergantung akan ketersediaan alat dan bahan yang akan dipergunakan. Apabila alat dan bahan yang akan digunakan memadai, maka pelaksanaannya akan lebih baik.

Kesesuaian materi antara praktikum Kimia Dasar dengan mata kuliah Kimia Dasar telah dijelaskan di kajian pustaka. Tiap praktikum memiliki kesesuaian dengan materi Kimia Dasar. Sebelum melakukan praktikum, mahasiswa diharuskan mengikuti kegiatan pra lab atau biasa disebut dengan responsi. Pada proses responsi, mahasiswa diberikan sejumlah pertanyaan menyangkut keterkaitan materi dengan praktikum yang akan dijalankan. Pelaksanaan responsi dilakukan untuk menggali lebih dalam lagi pengetahuan (kognitif) tiap individu sehingga diharapkan dapat membantu dalam memahami keterkaitan materi. Pada proses pembuatan laporan, mahasiswa diharapkan mampu mengintegrasikan materi, kegiatan, dan hasil pengamatan pada laporan yang dibuat.

Praktikum pembuatan larutan mewakili materi reaksi dalam larutan dan stoikiometri. Praktikum netralisasi asam basa mewakili materi reaksi dalam larutan, stoikiometri, dan ikatan kimia. Praktikum termokimia mewakili materi hubungan energi dalam reaksi kimia. Praktikum kinetika kimia mewakili materi stoikiometri dan reaksi dalam larutan. Praktikum elektrolisis larutan kalium iodide mewakili materi stoikiometri dan reaksi dalam larutan.

Keterkaitan antara materi praktikum dengan perkuliahan Kimia Dasar dapat dilihat dari kesesuaian materi diantara keduanya.

Ada beberapa faktor yang mempengaruhi jalannya proses perkuliahan. Faktor-faktor yang dimaksud seperti faktor internal meliputi psikologi, jasmani, dan lain-lain. Faktor eksternal yang meliputi keluarga, suasana kampus, dan masyarakat.

\section{SIMPULAN}

Berdasarkan hasil penelitian dan pembahasan yang telah 
Anggraini, P. Dian. 2016. Analisis Kesulitan Mahasiswa dalam Perkuliahan 71 dan Praktikum Kimia Dasar di Jurusan Pendidikan Biologi FKIP UNISBA.

Konstruktivisme, 8(1): 61-71.

disampaikan pada bagian sebelumnya maka dapat diambil beberapa kesimpuan bahwa:

1. Hambatan yang menyebabkan kesulitan belajar kimia dasar mahasiswa Jurusan Pendidikan Biologi adalah ada pada kemmpuan penguasaan materi dan pelaksanaan praktikum

2. Selanjutnya diketemukan bahwa benar ada korelasi yang berarti antara nilai praktikum Kimia Dasar dengan nilai teori Kimia Dasar mahasiswa Jurusan Pendidikan Biologi FKIP UNISBA

3. Pada faktor lingkungan masyarakat, secara statistik didapatkan bahwa secara kseseluruhan dari delapn faktor yang diselidiki memiliki pengaruh cukup besar yaitu $66,15 \%$.

\section{DAFTAR PUSTAKA}

Abdurrahman, Mulyono.1999. Pendidikan Bagi Anak Berkesulitan Belajar. Jakarta: Rineka Cipta

Anonim A. 2010. Faktor-fakror yang mempengaruhi kesulitan belajar ekonomi. Online oktober 10, 2010. Makassar : http//. www. Kesulitan belajar.com.

Arjumiati. 2005. Kemampuan Dasar Mahasiswa Angkatan 2004 Jurusan Kimia FMIPA Universitas Negeri Makassar pada Materi Kimia Dasar. Skripsi. Makassar FMIPA UNM

Caswilan, 2010, Hubungan Prestasi Belajar PKn dengan Pemahaman Sistem Politik Siswa SMK, www.google.com, diakses tanggal 22 juni 2010.

Darminto, 2006. Pembelajaran Kimia yang Berkualitas. Jurnal Kimia dan Pendidikan Kimia "Chemica", Edisi Khusus 2 Oktober 2006, Universitas Negeri Makassar.

Haedarsih, 2004, Hubungan Antara Prestasi Belajar Kimia Anorganik I dan II dengan Praktikum Kimia Anorganik Mahasiswa Program Studi Pendidikan Kimia FMIPAUNM Angkatan 1999-2001, Skripsi.

Hastutiningsih, 2007, Peningkatan Hasil Belajar Biologi Siswa Kelas XI IPA 3 SMA Negeri 1 Natar dengan Metode Inquiry, Lampung Selatan, Lampung.

Irawati. 2008. Analisis Tingkat Kesulitan Menyelesaikan Soal-Soal pada Materi Stokiometri Bagi Siswa X SMA Negeri 2 Makassar. Skripsi: Makassar. FMIPA UNM.

Limbrawaty, 2005, Hubungan Antara Nilai Mata Kuliah Kimia Analitik II dengan Nilai Kimia Analisis Instrumen Mahasiswa Program Studi Pendidikan Kimia Angkatan Tahun 2004, Skripsi tidak diterbitkan, Makasar FMIPA UNM. 